\title{
Estimating the onset of dispersal in endangered Bonelli's Eagles Hieraaetus fasciatus tracked by satellite telemetry: a comparison between methods
}

\author{
LUIS CADAHÍA, ${ }^{1,2 *}$ PASCUAL LÓPEZ-LÓPEZ, ${ }^{1,3}$ \\ VICENTE URIOS ${ }^{1} \&$ JUAN J. NEGRO ${ }^{2}$ \\ ${ }^{1}$ Estación Biológica Terra Natura (Fundación Terra \\ Natura - CIBIO), Universidad de Alicante, Apdo. \\ correos 99, E-03080, Alicante, Spain \\ ${ }^{2}$ Departamento de Ecología Evolutiva, Estación Biológica \\ de Doñana, CSIC. Avda. de María Luisa, s/n, Pabellón del \\ Perú, 41013, Sevilla, Spain \\ ${ }^{3}$ 'Cavanilles' Institute of Biodiversity and Evolutionary \\ Biology, University of Valencia, Polígono de la Coma $s / n$, \\ 46980 Paterna, Valencia, Spain
}

Keywords: Argos satellite telemetry, dispersal detection, GPS satellite telemetry, spatial ecology, tracking.

Dispersal is an essential process in population biology (Gadgil 1971, Johnson \& Gaines 1990, Kenward et al. 2002) that links diverse ecological, evolutionary and behavioural factors (Andreassen et al. 2002). Howard (1960) and Berndt and Sternberg (1968) called the movement of a bird leaving its natal home range and thereafter settling in a breeding site 'dispersal' and Greenwood and Harvey (1982) named it 'natal dispersal'. Kenward et al. $(2001,2002)$ proposed a more detailed description of these movements, based on defining home range as an 'area repeatedly traversed within a life path' (Burt 1943, Kenward et al. 2001) and dispersal as a 'unidirectional movement between home ranges'. Dispersal consists of three sequential, behaviourally different phases: emigration, transfer and immigration (Andreassen et al. 2002). The emigration phase, corresponding to the end of the postfledging period (Tyack et al. 1998, Mínguez et al. 2001) when juveniles become independent from their parents and depart from the natal home range, is usually difficult to determine precisely. Because of this, dispersal can be

${ }^{*}$ Corresponding author.

Email: luis.cadahia@gmail.com best detected by post-hoc examination of the data (Kenward et al. 2002). Even then, determination of the 'onset of dispersal' is not straightforward and different studies have defined this differently (e.g. Ferrer 1993, Kenward et al. 1993, Walls \& Kenward 1995, Cadahía et al. 2005). Several factors, including the accuracy of the tracking system or the rate at which location data are collected, may make it difficult to estimate precisely when birds leave their natal territories. Moreover, the onset of dispersal may not always be a particular event, but rather a process, in which juveniles progressively detach from their parents and their natal territory (e.g. 'local dispersal' in Spanish Imperial Eagles Aquila adalberti; Ferrer 2001). Accurately detecting the departure from the natal home range is important in understanding how different factors shape dispersal behaviour and influence when individuals disperse and where they settle afterwards. Some of these factors are food availability and nutritional condition of nestlings (Ferrer 1992, Wood et al. 1998, Kenward et al. 2001, Balbontín \& Ferrer 2005), sex (Kenward et al. 1993) or presence of siblings (Massot \& Clobert 2000, Massot et al. 2003).

The difficulty of detecting post hoc the onset of dispersal becomes particularly apparent when studying animals by satellite telemetry using the Argos system. This is a satellite-based transmitter location and data collection system that operates at a global scale (Argos 1996, Kenward 2001). The alternative GPS system operates through a different network of satellites and provides better accuracy than that of Argos, and the recent availability of lightweight GPS transmitters has enabled its use in studies of bird movements. Here we assess the performance of different methods aimed at detecting the onset of dispersal in satellite-tracked Bonelli's Eagles Hieraaetus fasciatus, an 'endangered' raptor in Europe (Real 2004), by using two different approaches. First, we compare the relative consistency among methods using only Argos tracking data. Secondly, we compare these results with GPS data from two juveniles experimentally fitted with combined Argos/GPS transmitters. We describe the onset of dispersal and compare the results with those obtained when applying the methods quoted above to the Argos data from these two birds. The relative performance of the methods and their advantages and drawbacks are discussed.

\section{METHODS}

\section{Tagging of birds}

Between 2002 and 2004 we tagged 14 juvenile Bonelli's Eagles with satellite transmitters (PTTs, platform transmitter terminals) in eastern Spain (Communities of Valencia, Catalonia and Murcia), 12 nestlings and two recent fledglings, by using a breakaway Teflon harness (Kenward 2001). Blood samples were used to sex the individuals (Griffiths et al. 1998, Fridolfsson \& Ellegren 1999). Birds 
Table 1. Methods used to estimate age at the onset of dispersal in 14 Bonelli's Eagles tracked by satellite telemetry in Spain.

\begin{tabular}{|c|c|c|c|c|}
\hline Method & Description & Advantages & Disadvantages & Reference(s) \\
\hline 1 & $\begin{array}{l}\text { First day beyond average } \\
\text { inter-nest distance }(11.4 \mathrm{~km}) \text {. }\end{array}$ & $\begin{array}{l}\text { Simple to compute } \\
\text { fixes beyond } \\
\text { threshold. }\end{array}$ & $\begin{array}{l}\text { Requires natal territory } \\
\text { data; biased by } \\
\text { excursive behaviour. }\end{array}$ & Soutullo et al. (2006). \\
\hline 2 & $\begin{array}{l}\text { First day beyond circular } \\
\text { parental territory (radius } \\
\text { half the inter-nest distance, } \\
5.7 \mathrm{~km} \text { ). }\end{array}$ & $\begin{array}{l}\text { Simple to compute } \\
\text { fixes beyond } \\
\text { threshold. }\end{array}$ & $\begin{array}{l}\text { Requires natal territory } \\
\text { data; biased by } \\
\text { excursive behaviour. }\end{array}$ & $\begin{array}{l}\text { McLeod et al. (2002), } \\
\text { Soutullo et al. (2006). }\end{array}$ \\
\hline 3 & $\begin{array}{l}(1)+\text { not within that distance } \\
\text { for the next two records. }\end{array}$ & $\begin{array}{l}\text { Minimizes excursion- } \\
\text { based bias. }\end{array}$ & $\begin{array}{l}\text { Requires natal } \\
\text { territory data. }\end{array}$ & $\begin{array}{l}\text { Kenward et al. (1993), } \\
\text { Walls and Kenward (1995). }\end{array}$ \\
\hline 4 & $\begin{array}{l}(2)+\text { not within that distance } \\
\text { for the next two records. }\end{array}$ & $\begin{array}{l}\text { Minimizes excursion- } \\
\text { based bias. }\end{array}$ & $\begin{array}{l}\text { Requires natal } \\
\text { territory data. }\end{array}$ & $\begin{array}{l}\text { Kenward et al. (1993), } \\
\text { Walls and Kenward (1995). }\end{array}$ \\
\hline 5 & Observed location pattern. & $\begin{array}{l}\text { Observation of } \\
\text { pattern of all } \\
\text { locations. }\end{array}$ & $\begin{array}{l}\text { Unlike the rest, it is } \\
\text { not computed, i.e. it is } \\
\text { a subjective method. }\end{array}$ & Walls and Kenward (1995). \\
\hline 6 & $\begin{array}{l}\text { Date halfway through the } \\
\text { 30-day 'month' with maximum } \\
\text { CV in distance to the nest. }\end{array}$ & $\begin{array}{l}\text { Computed from } \\
\text { distribution of all } \\
\text { locations. }\end{array}$ & $\begin{array}{l}\text { Requires many and } \\
\text { frequent location data. }\end{array}$ & Soutullo et al. (2006). \\
\hline 7 & $\begin{array}{l}\text { Date halfway through the three } \\
\text { consecutive location period } \\
\text { (one record forward each time) } \\
\text { with maximum CV in distance } \\
\text { to the nest. }\end{array}$ & $\begin{array}{l}\text { Computed from } \\
\text { distribution of all } \\
\text { locations. }\end{array}$ & $\begin{array}{l}\text { Requires many and } \\
\text { frequent location data. }\end{array}$ & Soutullo et al. (2006). \\
\hline 8 & $\begin{array}{l}\text { Date halfway through the five } \\
\text { consecutive location period } \\
\text { (one record forward each time) } \\
\text { with maximum CV in distance } \\
\text { to the nest. }\end{array}$ & $\begin{array}{l}\text { Computed from } \\
\text { distribution of all } \\
\text { locations. }\end{array}$ & $\begin{array}{l}\text { Requires many and } \\
\text { frequent location data. }\end{array}$ & Soutullo et al. (2006). \\
\hline 9 & $\begin{array}{l}\text { Date halfway through the ten } \\
\text { consecutive location period } \\
\text { (one record forward each time) } \\
\text { with maximum CV in distance } \\
\text { to the nest. }\end{array}$ & $\begin{array}{l}\text { Computed from } \\
\text { distribution of all } \\
\text { locations. }\end{array}$ & $\begin{array}{l}\text { Requires many and } \\
\text { frequent location data. }\end{array}$ & Soutullo et al. (2006). \\
\hline
\end{tabular}

were fitted with three types of PTTs: five 30-g batterypowered PTT-100s, seven 35-g solar-powered PTT-100s and two 45-g Argos/GPS PTT-100s, manufactured by Microwave Telemetry, Inc. (www.microwavetelemetry.com). Transmitters were set to an 8 -h on/120-h off duty cycle, except for the two Argos/GPS PTTs, which were set to a 16-h on/72-h off cycle. Argos/GPS transmitters permit birds to be tracked by the Argos and the GPS systems simultaneously. Transmitter weight never exceeded $3 \%$ of the birds' body mass $(2.1 \pm 0.5 \% \mathrm{sd} ; n=$ 14; range: $1.3-3.0 \%)$, as recommended by Kenward (2001).

Location estimation was made by the Argos system. Argos location classes (LC) 3, 2 and 1, with nominal accuracy $<150,150-350$ and 350-1000 $\mathrm{m}$, respectively, were used in this study (Argos 1996; but see Keating et al. 1991, Soutullo et al. 2007). We also included locations of lower quality (LC $0, A$ and B), using available information on Eagle movements, based on high-quality GPS data and on Argos accuracy tests (Cadahía et al. 2007, Soutullo et al. 2007), to filter the datasets.

\section{Onset of dispersal in Argos-tracked birds}

Birds were tracked throughout their first year of life or until the PTT signal was lost. The onset of dispersal was defined as the moment when juveniles became independent of their parents. A comparison between nine methods aimed at identifying this moment was performed (Soutullo et al. 2006). The methods are shown in Table 1. Methods 1-4 used a minimum distance beyond which birds were considered to have dispersed and were based on the average distance between nests in the region where birds were tagged $(10.1-12.7 \mathrm{~km}$; mean $=11.4 \mathrm{~km}$, $n=205$; Arroyo et al. 1995). Method 5 assumed the onset of dispersal happened the first day after the abrupt departure from the natal area and subsequent settlement in a different range (Walls \& Kenward 1995), based on visual observation of the pattern of locations. Methods 6-9 assumed that the onset of dispersal was characterized by the contrast between the restricted pre-dispersal movements and the subsequent exploratory stage, which would probably be reflected by an increased variability in 
Table 2. Age (in days) at the onset of dispersal in 14 Bonelli's Eagles estimated by nine different methods based on either the natal home range size or the patterns of movement in Spain. Methods 1-9 are described in Table 1.

\begin{tabular}{|c|c|c|c|c|c|c|c|c|c|c|}
\hline \multirow[b]{2}{*}{ Bird } & \multirow[b]{2}{*}{ Sex } & \multicolumn{9}{|c|}{ Method } \\
\hline & & 1 & 2 & 3 & 4 & 5 & 6 & 7 & 8 & 9 \\
\hline 1 & $\mathrm{~F}$ & 150 & 134 & 150 & 134 & drifter ${ }^{*}$ & 153 & 145 & 144 & 144 \\
\hline 2 & $M$ & 177 & 120 & 177 & 177 & 183 & 121 & 177 & 177 & 162 \\
\hline 3 & $\mathrm{~F}$ & 150 & 150 & 150 & 150 & 156 & 102 & 150 & 150 & 150 \\
\hline 4 & $M$ & 158 & 147 & 158 & 158 & 158 & 133 & 147 & 147 & 158 \\
\hline 5 & $\mathrm{~F}$ & 114 & 114 & 114 & 114 & 114 & 102 & 103 & 93 & 114 \\
\hline 6 & $\mathrm{~F}$ & 135 & 85 & 135 & 135 & 135 & 127 & 112 & 107 & 90 \\
\hline 7 & $\mathrm{~F}$ & 152 & 152 & 163 & 152 & 163 & 156 & 152 & 152 & 141 \\
\hline 8 & $\mathrm{~F}$ & 136 & 109 & signal lost & 136 & signal lost & 125 & 125 & 157 & 141 \\
\hline 9 (Argos) & M & 90 & 63 & 150 & 63 & 150 & 95 & 147 & 144 & 141 \\
\hline 10 (Argos) & $\mathrm{F}$ & 111 & 108 & 147 & 147 & 174 & 154 & 144 & 168 & 159 \\
\hline 9 (GPS) & $M$ & 141 & 133 & 145 & 133 & 151 & 127 & 96 & 113 & 150 \\
\hline 10 (GPS) & $F$ & 132 & 121 & 159 & 121 & 183 & 167 & 112 & 157 & 156 \\
\hline 11 & $M$ & 138 & 90 & 154 & 127 & 154 & 146 & 148 & 143 & 138 \\
\hline 12 & $\mathrm{~F}$ & 109 & 109 & 141 & 141 & 141 & 120 & 135 & 135 & 130 \\
\hline 13 & $\mathrm{~F}$ & 130 & 130 & 135 & 130 & 140 & 140 & 135 & 135 & 130 \\
\hline 14 & $\mathrm{~F}$ & 131 & 131 & 148 & 148 & 148 & 140 & 136 & 136 & 148 \\
\hline Mean & & 134.4 & 117.3 & 147.8 & 136.6 & 151.3 & 129.6 & 139.7 & 142.0 & 139.0 \\
\hline $\mathrm{sd}$ & & 22.86 & 25.96 & 15.16 & 26.07 & 18.18 & 20.10 & 18.10 & 21.63 & 19.05 \\
\hline CV (\%) & & 17.0 & 22.1 & 10.3 & 19.1 & 12.0 & 15.5 & 13.0 & 15.2 & 13.7 \\
\hline
\end{tabular}

*Unlike other birds that dispersed and settled in other areas, drifters continued to wander after leaving the natal territory (Walls \& Kenward 1995). In this case, method 5 is unable to estimate any abrupt departure from the natal area and subsequent settlement in other range.

distance to the nest (Soutullo et al. 2006). This can be used to detect dispersal by dividing the study time into different length periods and calculating the coefficient of variation $(\mathrm{CV})$ of distances in each. The mid-point of the period in which the $\mathrm{CV}$ is maximum will be considered as the date of onset of dispersal. In method 6, 30-day months were used, whereas in methods 7-9, consecutive location periods, moving one record forward each time, were considered. Because of the duty cycle of the PTTs, the mean ( \pm sd) number of days between consecutive locations ranged from $0.07 \pm 0.27$ to $20.36 \pm 10.43$.

We used a Kruskal-Wallis test to compare the age at the onset of dispersal calculated by each method and a GamesHowell multiple comparison test (Zar 1999) to perform all two-method comparisons. Within every method, the $\mathrm{CV}$ was computed and used as a measure of internal consistency (Soutullo et al. 2006), making it possible to compare the relative amounts of variation between methods.

\section{Onset of dispersal in GPS-tracked birds}

The GPS data from the two Argos/GPS-tagged (nonsibling) birds were grouped into 10-day periods after fledging and the average distance to the nest in each period was computed. Analyses were carried out until day 160 after fledging, when one of the birds' signals was lost. Using
Kruskal-Wallis and Games-Howell tests, we obtained the age at the onset of dispersal estimated from the GPS data for these two birds. We compared this value with those estimated using only Argos data (from the same birds) by each of the nine methods explained above. All analyses were carried out with SPSS 13.0.

\section{RESULTS}

Table 2 shows the dispersal dates determined by the nine methods. On average, dispersal occurred in August, around the fifth month of life. Method 2 (circular parental territory radius) estimated a significantly lower age at dispersal than the others $(H=19.72, d f=8, P=0.011)$, but all other two-method comparisons were not significant (Games-Howell test $P>0.254$ ). The most consistent method, i.e. that with the lowest $\mathrm{CV}$, was method 3 (average inter-nest distance +2 records), followed by method 5 (observed location pattern). The highest variation occurred in the methods using the circular parental territory radius, i.e. 2 and 4, followed by method 1 (average inter-nest distance). Those methods involving the $\mathrm{CV}$ scored intermediate levels of consistency (Table 2).

When studying the post-fledging period of the two Argos/GPS-tagged birds, three distinct phases became 
apparent (Games-Howell test $P>0.058$ ). The first one lasted until the 20th day and the second one until the 105th day after fledging (91st and 176th days after hatching, respectively). We considered the onset of dispersal to happen at the beginning of the last phase (i.e. at the 105th day after fledging). When applying the nine methods to the Argos data of these two birds, the determination of dispersal using the GPS data was most similar to method 5 (observed location pattern; Table 2).

\section{DISCUSSION}

The nine methods intended to detect the onset of dispersal can be grouped into three different categories. The first one comprised methods $1-4$, which share the drawback that researchers have to decide subjectively upon the distance to set (e.g. Kenward et al. 1993, Ferrer 2001, Cadahía et al. 2005). In common with Soutullo et al. (2006), we found that using the inter-nest distance was more consistent than using the home range radius, because a circle (represented by its radius) probably does not realistically depict the shape of the parental territory. The condition introduced in methods 3 and 4, aimed at avoiding early detections caused by excursions (Kenward et al. 1993, Walls \& Kenward 1995), not only yielded the most consistent result, method 3 , but also estimated relatively late dispersal dates, indicating that other methods prematurely define excursions as dispersal for some individuals (Table 2). These methods can be useful when studying species in which detailed knowledge of natal territory size is available (e.g. Ferrer 1993). However, this is not usually the case because distance between nests may vary throughout the species' range and knowledge is often incomplete (Soutullo et al. 2006).

The second category comprised method 5 , and it is remarkable that this method presented elevated consistency and coincidence with the high-quality GPS data, despite being based on the observers' direct observations and interpretations of movement patterns. This is probably linked to the fact that some raptors tend to disperse abruptly (Kenward et al. 2002) and, accordingly, the mere observation of movement patterns in many raptor species would be enough to detect the onset of dispersal (e.g. Real et al. 1998). However, comparisons based on such subjectively established dispersal dates would probably not be reliable.

In the third category, methods 6-9, dispersal was detected using a mathematical approach (Soutullo et al. 2006). These methods should in principle be particularly useful because they require only the location data with no information about distribution or size of breeding territories. Nevertheless, they provided heterogeneous results in terms of consistency, mainly because of two factors. First, during the excursions that Bonelli's Eagle juveniles perform before definitively leaving the parental territory, the variability in distance to the nest may increase in a particular period, resulting in an enlarged CV value and, poss- ibly, in a premature detection of dispersal. Secondly, estimating centre-period dispersal dates may be too inaccurate when periods considered are too long because of the intermittent nature or low volume of data, as is the case in satellite telemetry (1-20 days in this study). In fact, the CV in method 6 was larger than in the remaining CVbased methods. The results regarding the CV-based methods are in complete disagreement with those of Soutullo et al. (2006) working on Golden Eagle Aquila chrysaetos. This is probably due to Golden Eagle being a less excursive disperser. Thus, CV-based methods may not be applicable in species with intense excursive behaviour.

The GPS system provides a greater number of fixes and its nominal accuracy is better than $15 \mathrm{~m}$ (Microwave Telemetry 2007). It supplies more frequent data than Argos, which would increase the reliability of method 5 and the CV-based methods. In addition, the relative inaccuracy of Argos locations would require larger thresholds when detecting dispersal by methods $1-4$ than would be necessary for GPS (or VHF) data. All these features make GPS tracking especially suitable for studying the postfledging period in detail, which is otherwise difficult to survey by conventional Argos telemetry, and for investigating animal movements in general, especially those over large distances for which VHF tracking may not be appropriate. However, GPS transmitters are still too large for monitoring a great number of species, especially small birds. Consequently, if GPS PTTs are not available, Argos telemetry is one of the best existing alternatives, particularly when surveying the movements of small birds that cover extensive areas. Because of this, methodological surveys such as the one presented here that aim at improving the quality of the investigations using Argos provide researchers with helpful tools to make decisions on their data.

Thanks are due to the Conselleria de Territori i Habitatge of the Generalitat Valenciana (J. Jiménez, P. Mateache, A. Izquierdo and A. García i Sanz), Consejería de Industria y Medio Ambiente of Región de Murcia (E. Aledo and E. Cerezo), Departament de Medi Ambient of the Generalitat de Cataluña (X. Parellada), the University of Barcelona (N. Pocino, J. Real and A. Tintó), the ICRA (M.R. Jané and T. Borau), the University Miguel Hernández (M. Carrete, J.A. Sánchez-Zapata) and the Spanish Ministerio de Medio Ambiente (V. García Matarranz, P. García Domínguez) for permission to access the nests, partial funding and priceless field assistance. This project was funded by the Terra Natura Foundation. We are grateful to Á. Soutullo, C. García and R. Kenward for critical comments on early drafts of the manuscript. L.C. and P.L.-L. are supported by FPU grants of the Spanish Ministerio de Educación y Ciencia (references AP2001-1444 and AP2005-0874, respectively). This paper forms part of L.C.'s $\mathrm{PhD}$ thesis at the University of Alicante.

\section{REFERENCES}

Andreassen, H.P., Stenseth, N.C. \& Ims, R.A. 2002. Dispersal behaviour and population dynamics of vertebrates. In Bullock, J.M., Kenward, R.E. \& Hails, R.S. (eds) Dispersal Ecology: 50-71. Oxford: Blackwell. 
Argos. 1996. Argos User's Manual. Toulouse: CLS/Service Argos.

Arroyo, B., Ferreiro, E. \& Garza, V. 1995. El águila perdicera (Hieraaetus fasciatus) en España. Censo, Reproducción y Conservación. Madrid: Technical Collection ICONA.

Balbontín, J. \& Ferrer, M. 2005. Factors affecting the length of the post-fledging period in the Bonelli's Eagle Hieraaetus fasciatus. Ardea 93: 189-198.

Berndt, R. \& Sternberg, H. 1968. Terms, studies and experiments on the problems of bird dispersion. Ibis 110: 256-269.

Burt, W.H. 1943. Territoriality and home range concepts as applied to mammals. J. Mamm. 24: 346-352.

Cadahía, L., Urios, V. \& Negro, J.J. 2005. Survival and movements of satellite-tracked Bonelli's Eagles Hieraaetus fasciatus during their first winter. Ibis 147: 415-419.

Cadahía, L., Urios, V. \& Negro, J.J. 2007. Bonelli's Eagle Hieraaetus fasciatus juvenile dispersal: hourly and daily movements tracked by GPS. Bird Study 54: 271-274.

Ferrer, M. 1992. Natal dispersal in relation to nutritional condition in Spanish Imperial Eagles. Ornis Scand. 23: 104-107.

Ferrer, M. 1993. Juvenile dispersal behaviour and natal philopatry of a long-lived raptor, the Spanish Imperial Eagle Aquila adalberti. Ibis 135: 132-138.

Ferrer, M. 2001. The Spanish Imperial Eagle. Barcelona: Lynx Edicions.

Fridolfsson, A.-K. \& Ellegren, H. 1999. A simple and universal method for molecular sexing of non-ratite birds. J. Avian Biol. 30:116-121.

Gadgil, M. 1971. Dispersal: population consequences and evolution. Ecology 52: 253-261.

Greenwood, P.J. \& Harvey, P.H. 1982. The natal and breeding dispersal of birds. Ann. Rev. Ecol. Syst. 13: 1-21.

Griffiths, R., Double, M.C., Orr, K. \& Dawson, R.J.G. 1998. A DNA test to sex most birds. Mol. Ecol. 7: 1071-1075.

Howard, W.E. 1960. Innate and environmental dispersal of individual vertebrates. Am. Midl. Nat. 63: 152-161.

Johnson, M.L. \& Gaines, M.S. 1990. Evolution of dispersal: theoretical models and empirical tests using birds and mammals. Ann. Rev. Ecol. Syst. 21: 449-480.

Keating, K.A., Brewster, W.G. \& Key, C.H. 1991. Satellite telemetry: performance of animal-tracking systems. J. Wildl. Manage. 55:160-171.

Kenward, R.E. 2001. A Manual for Wildlife Radio Tagging. London: Academic Press.

Kenward, R.E., Marcström, V. \& Karlbom, M. 1993. Postnestling behaviour in goshawks, Accipiter gentilis: I. The causes of dispersal. Anim. Behav. 46: 365-370.

Kenward, R.E., Walls, S.S. \& Hodder, K.H. 2001. Life path analysis: scaling indicates priming effects of social and habitat factors on dispersal distances. J. Anim. Ecol. 70: 1-13.
Kenward, R.E., Rushton, S.P., Perrins, C.M., Macdonald, D.W. \& South, A.B. 2002. From marking to modelling: dispersal study techniques for land vertebrates. In Bullock, J.M., Kenward, R.E. \& Hails, R.S. (eds) Dispersal Ecology: 50-71. Oxford: Blackwell.

Massot, M. \& Clobert, J. 2000. Processes at the origin of similarities in dispersal behavior among siblings. J. Evol. Biol. 13: 707-719.

Massot, M., Huey, R.B., Tsuji, J. \& van Berkum, F.H. 2003. Genetic, prenatal and postnatal correlates of dispersal in hatchling fence lizards (Sceloporus occidentalis). Behav. Ecol. 14: 650-655.

McLeod, D.R.A., Whitfield, D.P., Fielding, A.H., Haworth, P.F. \& McGrady, M.J. 2002. Predicting home range use by Golden Eagles Aquila chrysaetos in western Scotland. Avian Sci. 2: 183-198.

Microwave Telemetry. 2007. http://www.microwavetelemetry.com. Accessed 19 April 2007.

Mínguez, E., Angulo, E. \& Siebering, V. 2001. Factors influencing length of the post-fledging period and timing of dispersal in Bonelli's Eagle (Hieraaetus fasciatus) in Southwestern Spain. J. Raptor Res. 35: 228-234.

Real, J. 2004. Águila-azor perdicera, Hieraaetus fasciatus. In Madroño, A., González, C. \& Atienza, J.C. (eds) Libro Rojo de las Aves de España: 154-157. Madrid: Dirección General para la Biodiversidad-SEO/Birdlife.

Real, J., Mañosa, S. \& Codina, J. 1998. Post-nestling dependence period in the Bonelli's Eagle Hieraaetus fasciatus. Ornis Fenn. 75: 129-137.

Soutullo, Á., Urios, V., Ferrer, M. \& Peñarrubia, S. 2006. Postfledging behaviour in Golden Eagles Aquila chrysaetos: onset of juvenile dispersal and progressive distancing from the nest. Ibis 148: 307-312.

Soutullo, Á., Cadahía, L., Urios, V., Ferrer, M. \& Negro, J.J. 2007. Accuracy of lightweight satellite telemetry: a case study in the Iberian Peninsula. J. Wildl. Manage. 71: 10101015.

Tyack, A.J., Walls, S.S. \& Kenward, R.E. 1998. Behaviour in the post-nestling dependence period of radio-tagged Common Buzzards Buteo buteo. Ibis 140: 58-63.

Walls, S. \& Kenward, R. 1995. Movements of radio-tagged Buzzards Buteo buteo in their first year. Ibis 137: 177-182.

Wood, P.B., Collopy, M.W. \& Sekerak, C.M. 1998. Post-fledging nest dependence period for Bald Eagles in Florida. J. Wild. Manage. 62: 333-339.

Zar, J.H. 1999. Biostatistical Analysis, 4th edn. New Jersey: Prentice Hall. 